\title{
Seasonal Changes of Sedimentation Rates and Sediment Characteristics Status in the Gulf of Mannar Coral Island, India
}

\author{
J. S. Yogesh Kumar ${ }^{1, *}$, S. Geetha ${ }^{2}$, R. Sornaraj ${ }^{3}$ \\ ${ }^{1}$ Zoological Survey of India, Andaman and Nicobar Regional Centre, National Coral Reef Research \\ Institute, Port Blair - 744102, Andaman \& Nicobar Islands, India \\ ${ }^{2}$ Wetland Research and Development, Thoothukudi, Tamil Nadu, India \\ ${ }^{3}$ Kamaraj College, Thoothukudi, Tamil Nadu, India \\ *E-mail address: coralyogesh@yahoo.co.in
}

\begin{abstract}
Corals are known to flourish in various turbid environments around the world. The quantitative distinction between clear and turbid water in coral habitats is not well defined nor are the amount of sediment in suspension and rates of sedimentation used to evaluate the condition of reef environments well established. This study of sedimentation rate, sediment composition and $\mathrm{pH}, \mathrm{OC}$ deposition was on a fringing reef flat off Thoothukudi and Vembar group of islands, Gulf of Mannar, India. In the present study the sedimentation rate ranged from $1.97 \mathrm{mg} / \mathrm{cm}^{2} /$ day to $12.31 \mathrm{mg} / \mathrm{cm}^{2} /$ day. The percentage of sand in the sediment was higher than silt and clay. The organic carbon level in all the study stations ranged from 0.03 to 2.54 . The sediment $\mathrm{pH}$ of the six studied stations was highly acidic in nature at all the study sites in the Gulf of Mannar.
\end{abstract}

Keywords: Sedimentation; coral reef; Thoothukudi group; Vembar group; Gulf of Mannar; Indian

\section{INTRODUCTION}

Coral reefs typically grow in relatively clear waters. Land use practices such as overgrazing and coastal development can increase the supply of sediment to the nearshore where most coral reefs develop, creating a situation of stress or even killing of corals (Buddemeir and Hopley, 1998; Fortes, 2000). High suspended sediment concentrations can attenuate photosynthetically available radiation, which in turn reduces coral growth rates (Hubbard and Scature, 1985; Edmunds and Spencer-Davies, 1989), decreases net productivity (Rogers, 1979), and induces coral stress (Van Katwijk et al., 1993). Suspended sediment can also be a vector for the introduction of nutrients, toxic substances and heavy metals to reefs that can stress or kill corals (Rogers, 1990; Souter et al., 1993; Bastidas et al., 1999). For this reason sedimentation rate on a reef is considered as a highly important variable in studies of coral reefs, especially with the ever increasing levels of suspended sediment in the marine environment.

In many studies of coral reefs, the sedimentation rate is measured as one of the important stresses of pollutants on the reefs. Sedimentation from dredging and runoff 
constitutes one of the biggest threats of reef degradation from human activities (Endean, 1976; Chansang et al., 1981; Dahl, 1985; Hodgson and Dixon, 1988). Sometimes dredging and other activities which increase sediments in the water appear to cause only localized or negligible effects on corals (Dollar and Grigg, 1981; Brown and Howard, 1985).

The physical nature of the substratum, its nutrient and degree of stability has a direct influence on the organisms inhabiting that area. In the estuarine environment the substratum is generally composed of sediments brought in by the rivers and the tide. These sediments are termed as terrigenous sediments as they are derived from the adjacent land, where as the pelagic sediments are those precipitated from sea water or which have been deposited on the sea floor through the accumulation of the skeletal remains of planktonic marine organisms (Nair and Thampy, 1980). Marine sediments consist of gravel, coarse sand, fine sand, silt and clay. Microorganisms are also present in the sediment. The richness of nutrients in an aquatic system is mainly dependant on the sediments and sediment water interactions which affect the productivity (Nair et al., 1984). Estuarine sediments are richer in organic matter than those of the adjacent sea (Nixon and Lee, 1982).

The sediment characteristics have a predominant effect on the benthic fauna of the area. The dependability of species composition and abundance of benthic fauna on sedimentary characteristics has been emphasized by various workers (Chandran et al., 1982; Harkantra and Parulekar, 1987; Bhat and Neelakantan, 1988; Ansari et al., 1994; Chatterji et al., 1995). In the present study, maximum effort was taken to determine the rate of sedimentation, sediment texture, sediment effects on coral reefs and reef organisms in the Thoothukudi and Vembar group of islands, Gulf of Mannar.

\section{MATERIALS AND METHOD}

The sedimentation rates in the study area were measured by using a sediment trap. The sediment sample was collected using the sampling technique adopted by English et al. (1997). Sediment traps were placed at a depth of $3 \mathrm{~m}$ to $7 \mathrm{~m}$ and the sediment traps were deployed in six study sites with 4 traps in each site representing all directions (Fig. 8). Sediment samples were collected from sediment traps and taken to the laboratory for further analysis. Collected samples were expressed in $\mathrm{mg} / \mathrm{cm}^{2} /$ day. This was calculated by dividing the collected sediment weight by the number of days of immersion for that month, and multiplying this figure with the surface area of the cylinder (cylinder's bottom surface area and cylinder's side surface area). The rate of sedimentation was calculated from the collected samples for every month by the following procedure. The average weight of sediment from each site was divided by the total surface area of cylinder and converted for a day using the following formula.

Cylinder surface area $=2 \pi \mathrm{r}(\mathrm{r}+\mathrm{h})=2 \pi \mathrm{r}^{2}+2 \pi \mathrm{r} \mathrm{h}$.

Cylinder surface area $=220.38 \mathrm{~cm}^{2}$

$$
=2 \times 3.14 \times(2.5)^{2}+(2 \times 3.14 \times 2.5 \times 11.5)
$$

Rate of sedimentation $=$ weight of the sediment $/$ Cylinder surface area/month

The sediment textures are composite particles of size ranging from sand to clay, with their different combinations. The percentage of sand, silt and clay were estimated by the 
'pipette method', in accordance with the procedure adopted by Krumbein and Pettijohn (1938).

The percentage of organic carbon in the samples was estimated by the method of Walkley and Black (1934). The $\mathrm{pH}$ of the sediment samples were measured using 1:5 soil suspension in distilled water with the help of a Digital pH meter (Model L1-10).

The statistical tool correlation and ANOVA was employed using the software SPSS package to analyze the relationship between the various physical and chemical parameters of sediments in relation to the rate of sedimentation.

\section{RESULT}

\section{1. Rate of sedimentation}

Monthly variations in the rate of sedimentation for the study sites are given in Figure 1. The values indicated are the mean of observations and \pm standard deviation (SD).

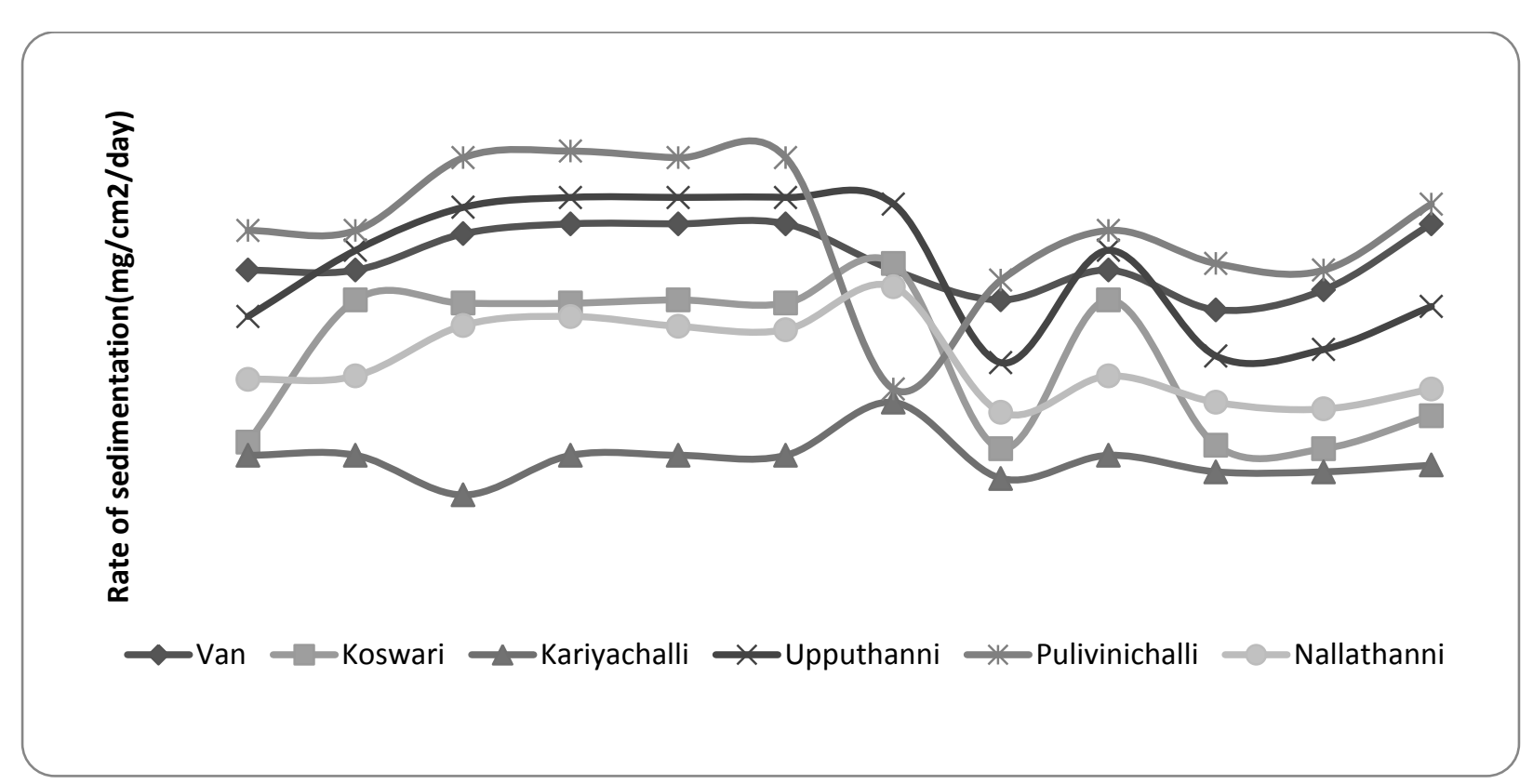

Figure 1. Monthwise rate of sedimentation $\left(\mathrm{mg} / \mathrm{cm}^{2} /\right.$ day) in the study stations during the study period (July 2007 to June 2008).

The sedimentation rate in Van island ranged between $7.5 \mathrm{mg} / \mathrm{cm}^{2} /$ day to 10.13 $\mathrm{mg} / \mathrm{cm}^{2} /$ day, in Koswari island between $3.29 \mathrm{mg} / \mathrm{cm}^{2} /$ day to $7.8 \mathrm{mg} / \mathrm{cm}^{2} /$ day, in Kariyachalli island between $1.96 \mathrm{mg} / \mathrm{cm}^{2} /$ day to $4.7 \mathrm{mg} / \mathrm{cm}^{2} /$ day, in Upputhanni island between 5.88 $\mathrm{mg} / \mathrm{cm}^{2} /$ day to $10.96 \mathrm{mg} / \mathrm{cm}^{2} /$ day, in Pulivinichalli island between $5.13 \mathrm{mg} / \mathrm{cm}^{2} /$ day to 12.3 $\mathrm{mg} / \mathrm{cm}^{2} /$ day, and in Nallathanni island between $4.4 \mathrm{mg} / \mathrm{cm}^{2} /$ day to $8.2 \mathrm{mg} / \mathrm{cm}^{2} /$ day (Fig. 1).

The highest value of sedimentation occurred in the month of October in Van Island and Pulivinichalli, January in Koswari, Kariyachalli and Nallathanni islands, November and December in Upputhanni Island. The lowest value of sedimentation occurred in the month of April in Van Island, May in Koswari, September in Kariyachalli, March in Upputhanni and January and February in Pulivinichalli and Nallathanni Islands. In all the study sites, highest 
rate of sedimentation was noticed during the monsoon season and lowest concentration was during the summer and post-monsoon season. It was noticed that greater variation in rate of sedimentation was recorded during the post-monsoon seasons. The month of October recorded the highest value of rate of sedimentation in most of the sites and February recorded the lowest value for most of the sites.

\section{2. Sediment texture}

The relative percentage of various size classes of the sediments of the six stations for a period of one year are graphically presented in Fig. 2, 3 and 4.

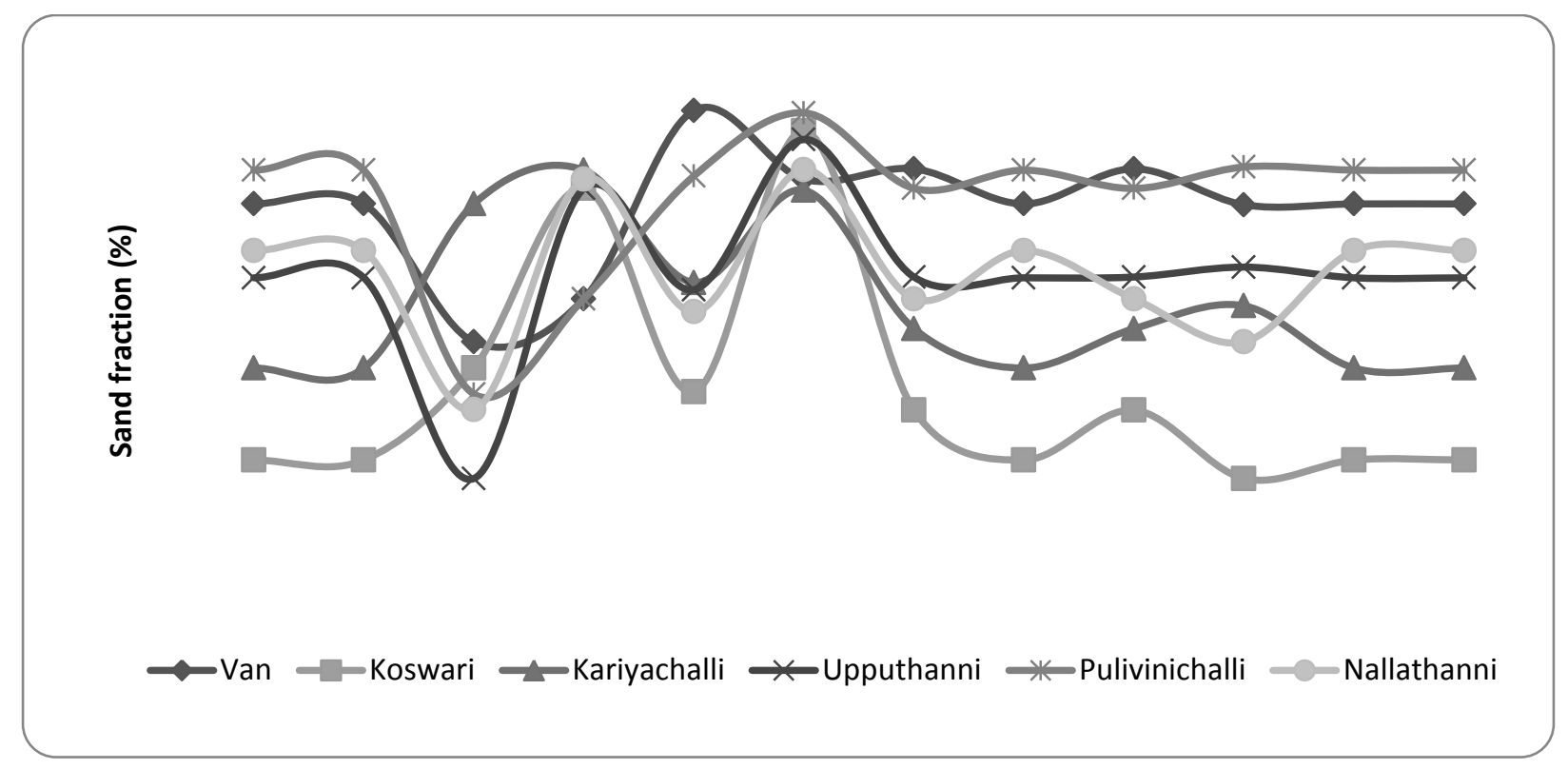

Figure 2. Monthwise observation of the percentage of sand fraction in the study stations during the study period (July 2007 to June 2008).

The percentage of sand fractions varied considerably for different months in this region. In Van island, the sand fraction ranged from $81.23 \%$ (September) to $92.21 \%$ (November), in Koswari island from $58.84 \%$ (April) to $90.35 \%$ (December), in Kariyachalli island ranged from $68.86 \%$ to $86.80 \%$ (October), in Upputhanni island ranged from $58.84 \%$ (September) to $89.59 \%$ (December), in Pulivinichalli island from $73.96 \%$ (September) to $92 \%$ (December) and Nallathanni island the minimum range observed was $71.23 \%$ (April) and maximum range observed was $92.21 \%$ (September) (Fig. 2).

Greater variation in sand fraction was observed during monsoon season for all the study stations (Fig. 2), whereas during the other seasons it remained steady. The month of December (Monsoon seasons) recorded the highest value of sand fraction and month of September recorded the lowest value of sand fraction for all the study stations. 


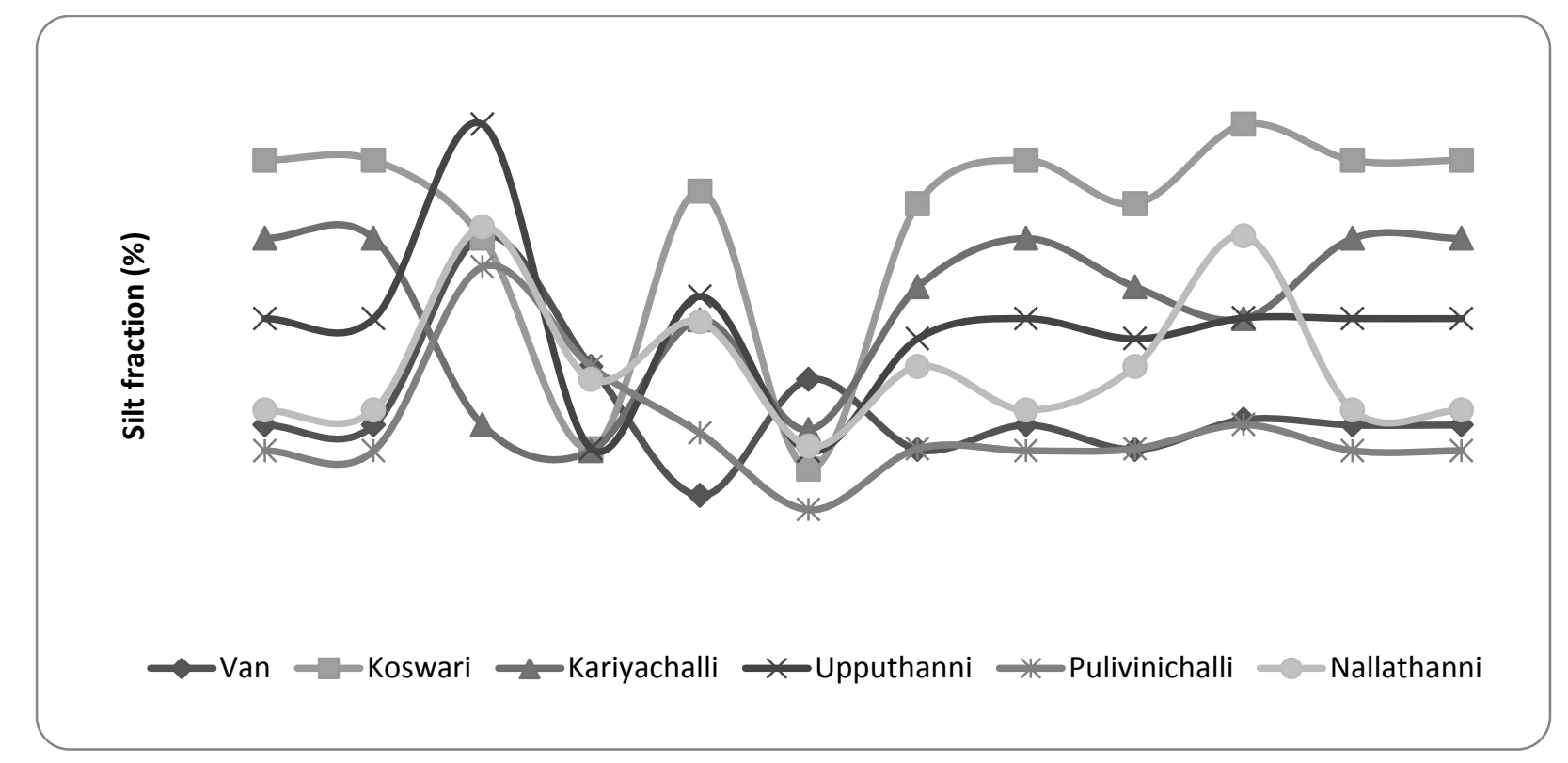

Figure 3. Monthwise observation of the percentage of silt fraction in the study stations during the study period (July 2007 to June 2008).

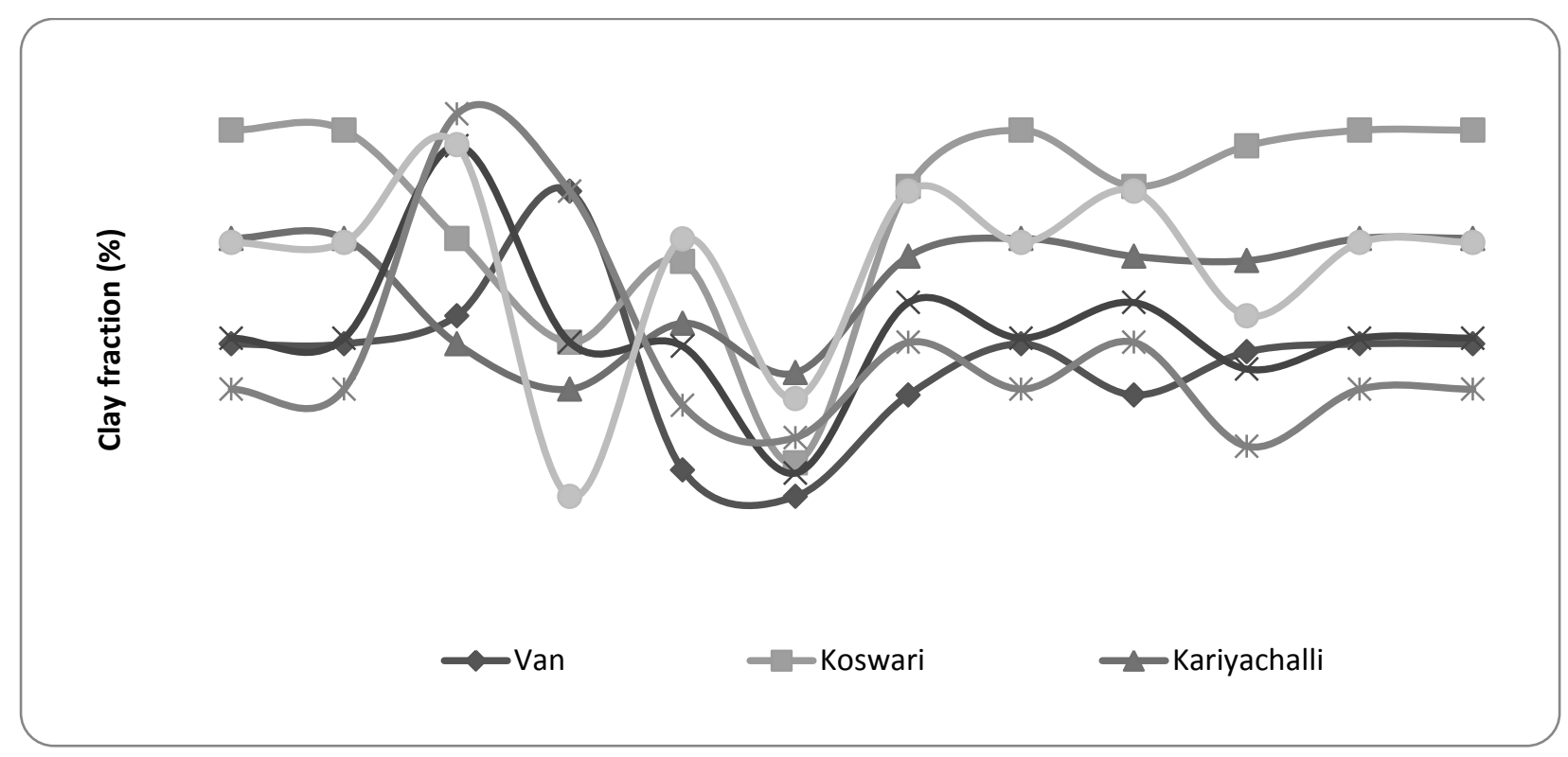

Figure 4. Monthwise observation of the percentage of clay fraction in the study stations during the study period.

Next to the sand fraction, considerable amount of silt fractions were observed in the study region (Fig. 2) which ranged from $4.56 \%$ (November) to $20.45 \%$ (September) in Van Island, $6.18 \%$ (December) to $27.26 \%$ (April) in Koswari Island, $7.31 \%$ (October) to 20.29 $\%$ (August) in Kariyachalli Island, $7.28 \%$ (December) to $27.26 \%$ (September) in Upputhanni Island, $3.7 \%$ (December) to $15.2 \%$ (September) in Pulivinichalli Island and $4.56 \%$ (September) to $20.45 \%$ (April). 
Considerable variations in silt fraction were noticed during the monsoon seasons for the study stations whereas during the other seasons there was not much variation. The month of September recorded the highest percentage of silt fraction and lowest values were recorded in December in the study stations.

The clay content in all the study stations was very scanty. It ranged from $2.36 \%$ (December) to $12.41 \%$ (October) in Van island, $3.47 \%$ (December) to $14.41 \%$ (May) in Koswari, $5.89 \%$ (October) to $10.85 \%$ (May) in Kariyachalli island, $3.13 \%$ (3.13\%) to 13.9 $\%$ (September) in Upputhanni Island, 4.01 (April) to $12.41 \%$ (October) in Pulivinichalli Island and $2.36 \%$ (October) to $12.41 \%$ (March) in Nallathanni Island.

The clay fraction showed greater variation during the monsoon season. In almost all the stations the clay fractions remain steady during all seasons. All the sites recorded lowest value of clay fraction during December.

The percentage of sand, silt and clay were plotted in Ternary plots (Fig. 5) for a period of one year. Most of the samples from the study sites fall in the class of sandy, silty sand and little clayey sand.

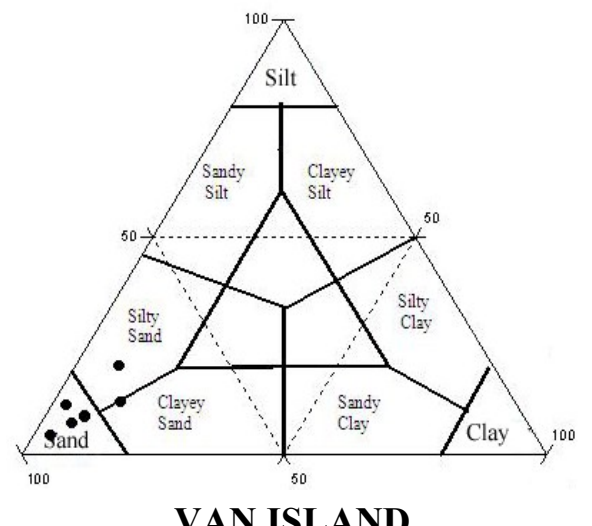

VAN ISLAND

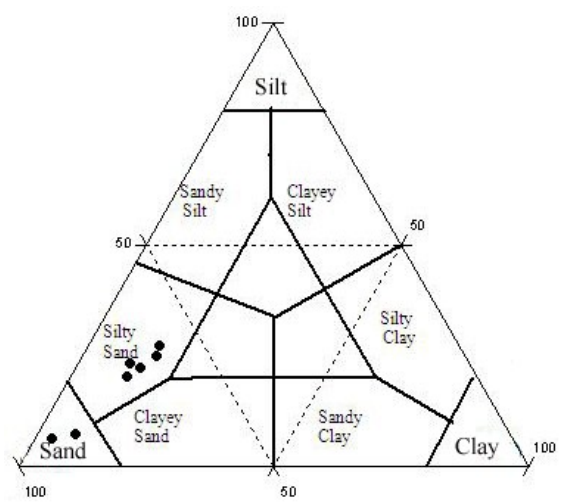

KOSWARI ISLAND

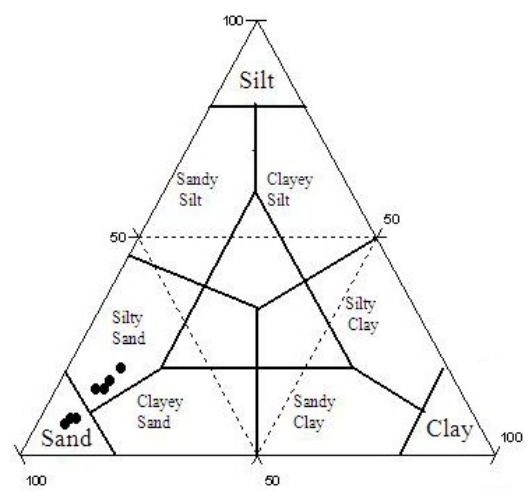

KARIYACHALLI ISLAND

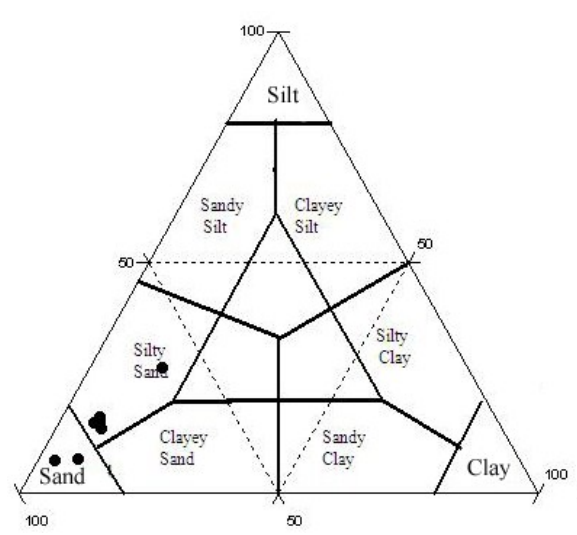

UPPUTHANNI ISLAND

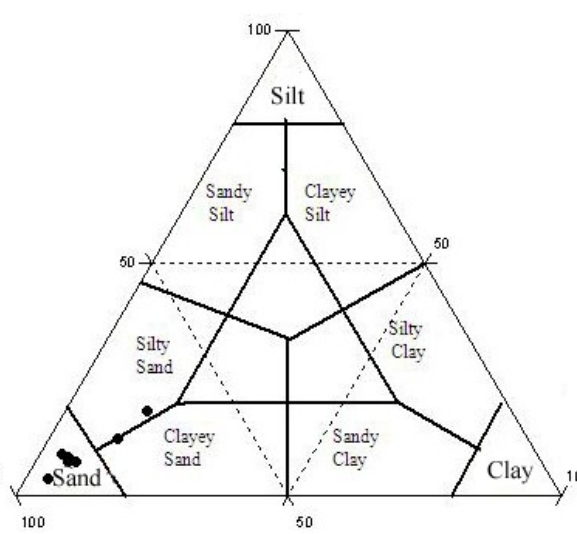

PULIVINICHALLI ISLAND

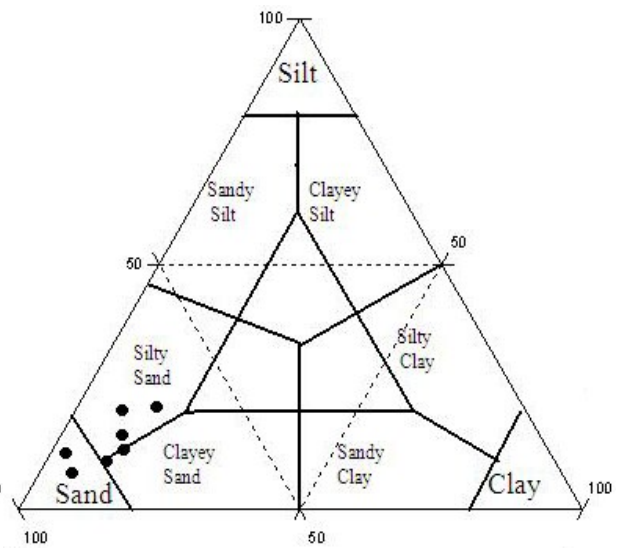

NALLATHANNI ISLAND

Figure 5. Ternary plots showing the sediment textural characteristics of six islands of Gulf of Mannar. 


\section{3. Organic carbon (OC)}

The percentages of organic carbon for the studied sediments are given in Fig. 6. The percentage of organic carbon ranged from $0.03 \%$ (January) to $0.93 \%$ (March) in Van island, $0.07 \%$ (September) to $2.33 \%$ (April) in Koswary, $0.04 \%$ (August) to $2.23 \%$ (April) in Kariyachalli, $0.03 \%$ (October) to $2.33 \%$ (July) in Upputhanni, $0.18 \%$ (August) to $2.24 \%$ (July) in Pulivinichalli and $0.13 \%$ (August) to $1.43 \%$ (April and May).

The result showed greater variation in the concentration of organic carbon during monsoon season and post monsoon season when compared with other seasons. It was observed that the percentage of organic carbon was increased from the late monsoon to postmonsoon and it decreased during the pre-monsoon. The maximum percentage of organic carbon varied for different stations in different months, however minimum percentage of organic carbon was recorded during the months of July, August and September in all the stations studied (Fig. 6).

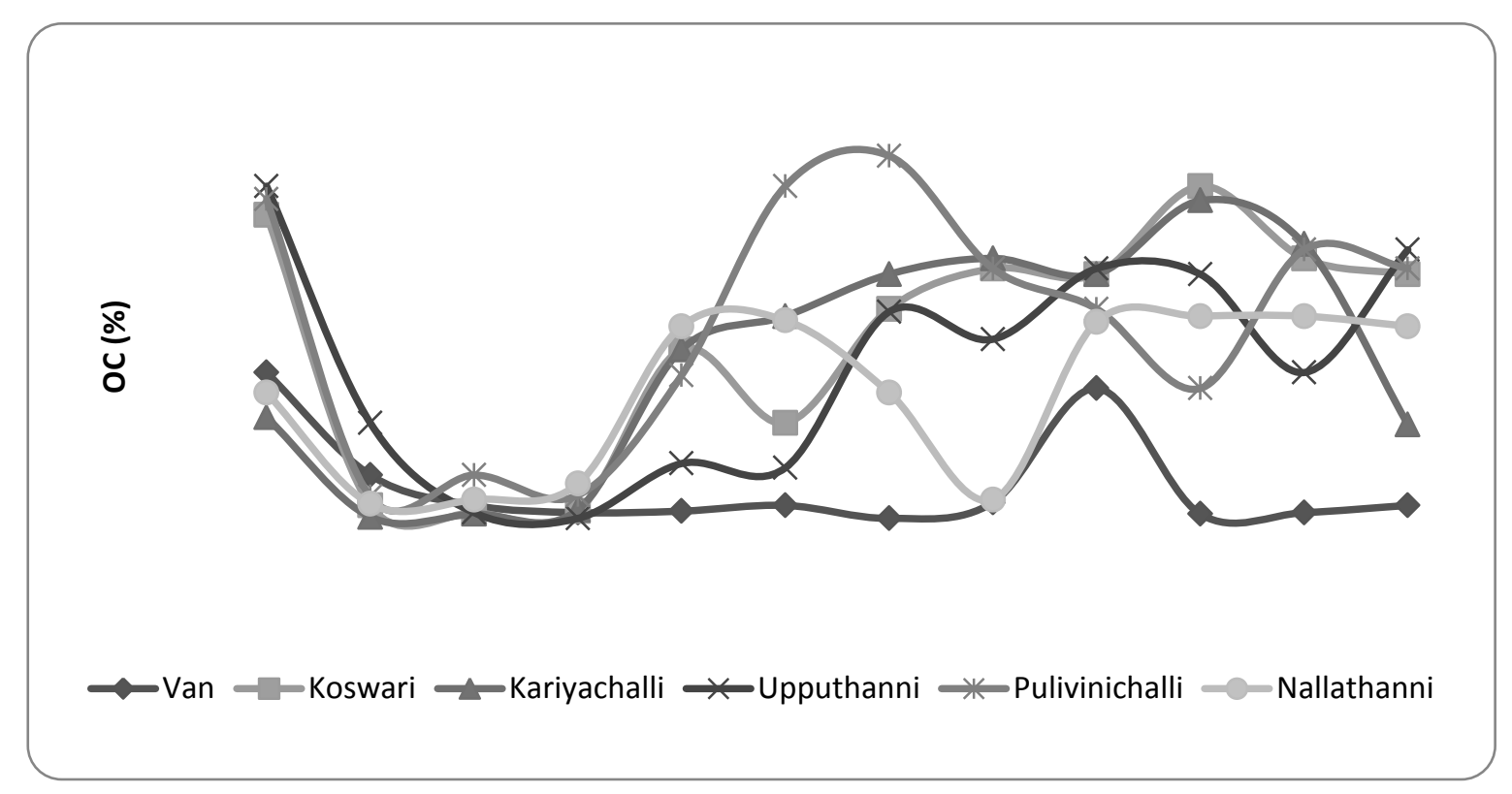

Figure 6. Monthwise observation of the percentage of organic carbon in the study stations during the study period.

\section{4. Sediment pH}

The $\mathrm{pH}$ of sediment ranged from 5.4 to 7.03 in Van Island, 5.37 to 7.27 in Koswari Island, 5.6 to 6.27 in Kariyachalli Island, 5.6 to 6.8 in Upputhanni Island, 5.2 to 6.63 in Pulivinichalli Island and 4.8 to 6.7 in Nallathanni Island (Fig. 7). Not much variation was observed in $\mathrm{pH}$ values of different study stations during different seasons. Minimum values of $\mathrm{pH}$ were recorded during the month of January and maximum values of $\mathrm{pH}$ were noted during the month of August. Maximum pH was observed during pre-monsoon (5.8 to 6.8) and minimum in monsoon (5.34 to 6.11) period. The analysis of variance showed that the high mean annual sediment $\mathrm{pH}$ was in Koswari Island (Table 3) and the lowest in Nallathanni Island (Table 7). 


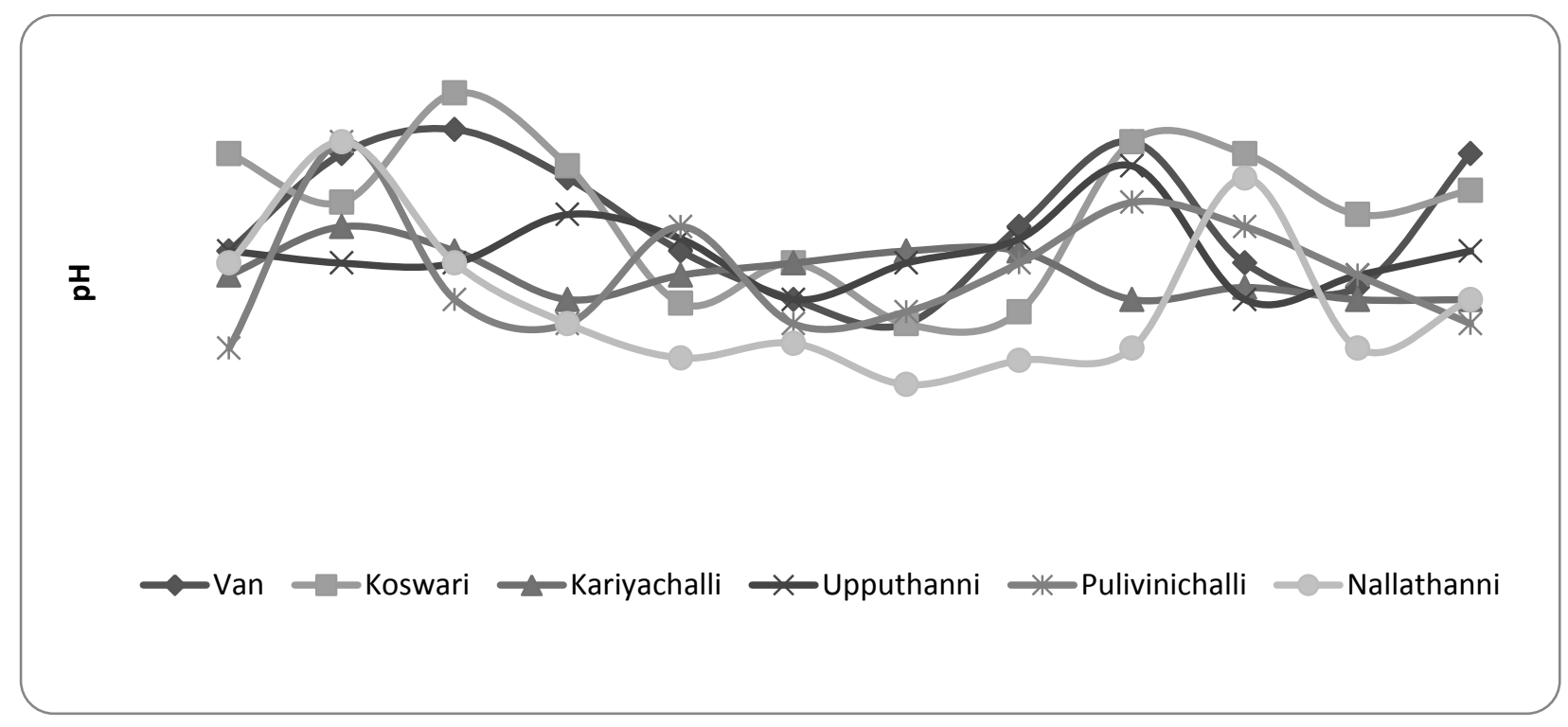

Figure 7. Monthwise observation of the mean variation of sediment $\mathrm{pH}$ of different stations during the study period (July 2007 to June 2008).

\section{5. Statistical analysis}

One way ANOVA result obtained between the station and month of all the study stations showed a significant deviation (Table 1) for all the studied parameters.

Table 1. Analysis of variance (F values) for the sediment structure of sediment and $\mathrm{OC}$ and $\mathrm{pH}$ between the stations and month during the study period (July 2007 - June 2008).

\begin{tabular}{|c|c|c|c|c|c|c|}
\hline Parameters & Variable & SS & Df & MS & F & Signi. \\
\hline \multirow{3}{*}{ Clay } & Station & 255.2 & 5 & 51 & 7.3 & 1.6 \\
\cline { 2 - 7 } & Month & 158.5 & 11 & 14.4 & 1.6 & 0.1 \\
\hline \multirow{3}{*}{ Silt } & Station & 1330.2 & 5 & 266 & 11.7 & 4.4 \\
\cline { 2 - 7 } & Month & 501.6 & 11 & 45.6 & 1.2 & 0.3 \\
\hline \multirow{3}{*}{ Sand } & Station & 2025.3 & 5 & 405.1 & 4.6 & 0.001 \\
\cline { 2 - 7 } & Month & 2133.8 & 11 & 193.9 & 2.1 & 0.03 \\
\hline \multirow{2}{*}{ Organic carbon } & Station & 150388.6 & 5 & 30077.7 & 23.4 & 1.8 \\
\cline { 2 - 7 } & Month & 43292.2 & 11 & 3935.7 & 1.2 & 0.2 \\
\cline { 2 - 7 } & Month & 19.3 & 11 & 1.8 & 4.4 & 0.005 \\
\hline \multirow{2}{*}{ Sediment pH } & Station & 4.8 & 5 & 0.9 & 3.9 & 0.004 \\
\cline { 2 - 7 } & Month & 5.89 & 11 & 0.5 & 2.1 & 0.03 \\
\hline
\end{tabular}


The correlation analysis also showed significant variations among the studied parameters in relation to the rate of sedimentation. In Van island significant negative correlation was found between the rate of sedimentation and the sand, silt, clay where as the $\mathrm{pH}$ and silt showed positive correlation which meant that the rate of sedimentation enhanced the $\mathrm{pH}$ and silt accumulation.

In Koswari and Upputhanni Island sedimentation rate showed negative significant correlation between the organic carbons (OC) and OC significantly correlated negatively with sand and positively correlated with silt. Silt was positively correlated with clay, in Kariyachalli, Upputhanni, Pulivinichalli and Nallathanni Island and sand showed significant negative correlation with the silt and clay (Tables 2 to 7 ).

Table 2. Correlation coefficient ( $\mathrm{r}$ ) values obtained between various sediment structures of sediment during the study period (July 2007 - June 2008) at Van Island.

\begin{tabular}{|c|c|c|c|c|c|c|}
\hline Van island & $\begin{array}{c}\text { Rate of } \\
\text { sedimen } \\
\text { tation } \\
\end{array}$ & pH & OC & Sand & Silt & Clay \\
\hline $\begin{array}{c}\text { Rate of } \\
\text { sedimentation } \\
\text { pH }\end{array}$ & $\begin{array}{c}1 \\
.361\end{array}$ & 1 & & & & \\
\hline OC & -.159 & .230 & 1 & & & \\
\hline Sand & -.173 & -.545 & .142 & 1 & & \\
\hline Silt & .287 & .437 & -.176 & $-.905(* *)$ & 1 & \\
\hline Clay & -.071 & .497 & -.034 & $-.755(* *)$ & .404 & 1 \\
\hline
\end{tabular}

Correlation is significant at the 0.01 level (2-tailed).

Table 3. Correlation co-efficient ( $\mathrm{r}$ ) values obtained between various sediment structure of sediments during the study period (July 2007 June 2008) at Kaswori Island.

\begin{tabular}{|c|c|c|c|c|c|c|}
\hline Koswari island & $\begin{array}{c}\text { Rate of } \\
\text { sedimen } \\
\text { tation }\end{array}$ & pH & OC & Sand & Silt & Clay \\
\hline $\begin{array}{c}\text { Rate of } \\
\text { sedimentation }\end{array}$ & 1 & & & & & \\
pH & -0.114 & 1 & & & & \\
OC & $-.698(*)$ & -0.138 & 1 & & & \\
Sand & 0.527 & -0.05 & $-.595\left(^{*}\right)$ & 1 & & \\
Silt & -0.498 & 0.02 & $.604\left(^{*}\right)$ & $-.993(* *)$ & 1 & 1 \\
Clay & -0.561 & 0.108 & 0.551 & $-.970(* *)$ & $.934(* *)$ & \\
\hline
\end{tabular}

* Correlation is significant at the 0.05 level (2-tailed).

** Correlation is significant at the 0.01 level (2-tailed). 
Table 4. Correlation coefficient (r) values obtained between various sediment structures of sediments during the study period (July 2007-June 2008) at Kariyachalli Island.

\begin{tabular}{|c|c|c|c|c|c|c|}
\hline $\begin{array}{c}\text { Kariyachalli } \\
\text { island }\end{array}$ & $\begin{array}{c}\text { Rate of } \\
\text { sedimen } \\
\text { tation }\end{array}$ & $\mathbf{p H}$ & OC & Sand & Silt & Clay \\
\hline $\begin{array}{c}\text { Rate of } \\
\text { sedimentation }\end{array}$ & 1 & & & & & \\
pH & 0.144 & 1 & & & & \\
OC & 0.137 & -0.276 & 1 & & & \\
Sand & -0.116 & -0.051 & -0.324 & 1 & & \\
Silt & 0.123 & 0.049 & 0.306 & $-.997(* *)$ & 1 & \\
Clay & 0.096 & 0.054 & 0.363 & $-.980(* *)$ & $.962(* *)$ & 1 \\
\hline
\end{tabular}

* Correlation is significant at the 0.05 level (2-tailed).

** Correlation is significant at the 0.01 level (2-tailed).

Table 5. Correlation coefficient (r) values obtained between various sediment structures of sediments during the study period (July 2007 -June 2008) at Upputhanni Island.

\begin{tabular}{|c|c|c|c|c|c|c|}
\hline $\begin{array}{c}\text { Upputhanni } \\
\text { island }\end{array}$ & $\begin{array}{c}\text { Rate of } \\
\text { sedimen } \\
\text { tation }\end{array}$ & pH & OC & Sand & Silt & Clay \\
\hline $\begin{array}{c}\text { Rate of } \\
\text { sedimentation }\end{array}$ & 1 & & & & & \\
pH & 0.158 & 1 & & & & \\
OC & $-.639(*)$ & 0.119 & 1 & & & \\
Sand & 0.041 & 0.061 & 0.042 & 1 & & \\
Silt & -0.115 & -0.153 & -0.003 & $-.983(* *)$ & 1 & \\
Clay & 0.118 & 0.139 & -0.118 & $-.925(* *)$ & $.841\left(^{* *}\right)$ & 1 \\
\hline
\end{tabular}

* Correlation is significant at the 0.05 level (2-tailed).

** Correlation is significant at the 0.01 level (2-tailed).

Table 6. correlation coefficient (r) values obtained between various sediment structures of sediments during the study period (July 2007-June 2008) at Pulivinichalli Island.

\begin{tabular}{|c|c|c|c|c|c|c|}
\hline $\begin{array}{c}\text { Pulivnichalli } \\
\text { island }\end{array}$ & $\begin{array}{c}\text { Rate of } \\
\text { sedimen } \\
\text { tation }\end{array}$ & pH & OC & Sand & Silt & Clay \\
\hline $\begin{array}{c}\text { Rate of } \\
\text { sedimentation }\end{array}$ & 1 & & & & & \\
pH & -0.044 & 1 & & & & \\
OC & -0.51 & -0.462 & 1 & & & \\
Sand & -0.338 & 0.188 & $.610\left(^{*}\right)$ & 1 & & \\
Silt & 0.333 & -0.112 & $-.656(*)$ & $-.977(* *)$ & 1 & 1 \\
Clay & 0.325 & -0.262 & -0.524 & $-.971\left(^{* *}\right)$ & $.897\left(^{* *}\right)$ & 1 \\
\hline
\end{tabular}

* Correlation is significant at the 0.05 level (2-tailed).

** Correlation is significant at the 0.01 level (2-tailed). 
Table 7. Correlation coefficient ( $\mathrm{r}$ ) values obtained between various sediment structure of sediments during the study period (July 2007-June 2008) at Nallathanni Island.

\begin{tabular}{|c|c|c|c|c|c|c|}
\hline $\begin{array}{c}\text { Nallathanni } \\
\text { island }\end{array}$ & $\begin{array}{c}\text { Rate of } \\
\text { sedimen } \\
\text { tation }\end{array}$ & $\mathbf{p H}$ & OC & Sand & Silt & Clay \\
\hline $\begin{array}{c}\text { Rate of } \\
\text { sedimentation }\end{array}$ & 1 & & & & & \\
pH & -0.349 & 1 & & & & \\
OC & -0.148 & -0.216 & 1 & & & \\
Sand & -0.028 & -0.182 & 0.036 & 1 & & \\
Silt & 0.152 & 0.317 & -0.05 & $-.860(* *)$ & 1 & 1 \\
Clay & -0.153 & -0.086 & 0 & $-.722(* *)$ & 0.268 & \\
\hline
\end{tabular}

* Correlation is significant at the 0.05 level (2-tailed).

** Correlation is significant at the 0.01 level (2-tailed).

Further, the $\mathrm{pH}$ of the sediment at the study areas had a significant inverse correlation with organic carbon and also the sediment $\mathrm{pH}$ negatively correlated with sand and positively correlated with silt and clay at Thoothukudi group of islands. Of all the islands studied, the Van and Upputhanni islands showed positive correlation between organic carbon and sand and negative correlation between silt and clay. But the other four islands showed negative correlation between organic carbon and sand and positive correlation between silt and clay. The statistical results showed that the rate of sedimentation enhanced the rate of $\mathrm{pH}$, silt, sand and clay accumulation in most of the studied sites.

\section{DISCUSSION AND CONCLUSIONS}

Sedimentation is a major controlling factor in the distribution of reef organisms and in overall reef development (Hubbard, 1986; Macintyre, 1988). Sedimentation and suspended sediments in the water column may affect the coral population and community structure by smothering adult corals or imposing physiological stress by reducing the light availability for photosynthesis or increasing the need for active sediment removal (Hudgson and Dixon, 1992). However, silt is generally resuspended significantly by lower bottom stress than sand and will stay in suspension much longer (Wright, 1995). Continual resuspension and transport of dredged sediments can cause sedimentation over the degraded coral reef years after dredging ceases (Brock et al., 1966; Grigg et al., 1972; Marsh and Gordon, 1974).

In the present study, the sedimentation rate ranged from $1.97 \mathrm{mg} / \mathrm{cm}^{2} /$ day to 12.31 $\mathrm{mg} / \mathrm{cm}^{2} /$ day (Fig. 1) which lay between the Indo-Pacific range of 0.1 to $228 \mathrm{mg} / \mathrm{cm}^{2} /$ day (Bray and Clark, 2004). According to Mathews et al. (2006), the highest rate of sedimentation occurred during the month of August and the lowest rate of sedimentation occured during the month of April in the Gulf of Mannar. But for the study period the maximum level of sedimentation was noted during October and minimum during September and it was noted that the rate of sedimentation was subject to seasonal variations, maximum during monsoon and minimum during pre-monsoon and summer seasons (Fig. 1). Coral skeleton contain a 
historical record of sedimentation events because they trap terrigenous sediments (Cortes and Risk, 1984). Fluorescent bands are indicators of runoff and large corals can provide a long record of runoff events (Isdale, 1984). But for the current study, the confirmation of sedimentation rate using fluorescent band was not possible because the study sites fall within the protected area.

Sediment characteristics are one among the many factors which have a direct control on any ecosystem (Boto and Wellington, 1984). Texture of sediments may favour organic production (Nixon and Lee, 1982). Weber et al. (1974) suggested that silt and clay sediments and nutrient rich sediment can stress the coral while sandy sediments or nutrient poor silt affect the coral to a lesser extent. In the present study also it was observed that the percentage of sand in the sediment was higher than silt and clay in all the study sites. In the present study all the study sites were found to have high percentage of sand fraction. Stephen et al. (2008) have reported that the grain sizes for Velankanni to Karaikal coast are in the order of sand, silt and clay. Muthuraj and Jayaprakash (2008) also reported $1.45 \%$ to $92.35 \%$ of sand and 7.65 $\%$ to $98.55 \%$ mud (Silt and clay) in the Bay of Bengal off Ennore coast. According to Ogston et al. (2004), the rate of sedimentation and sediment grain size is based on the flood, wave and wind pattern.

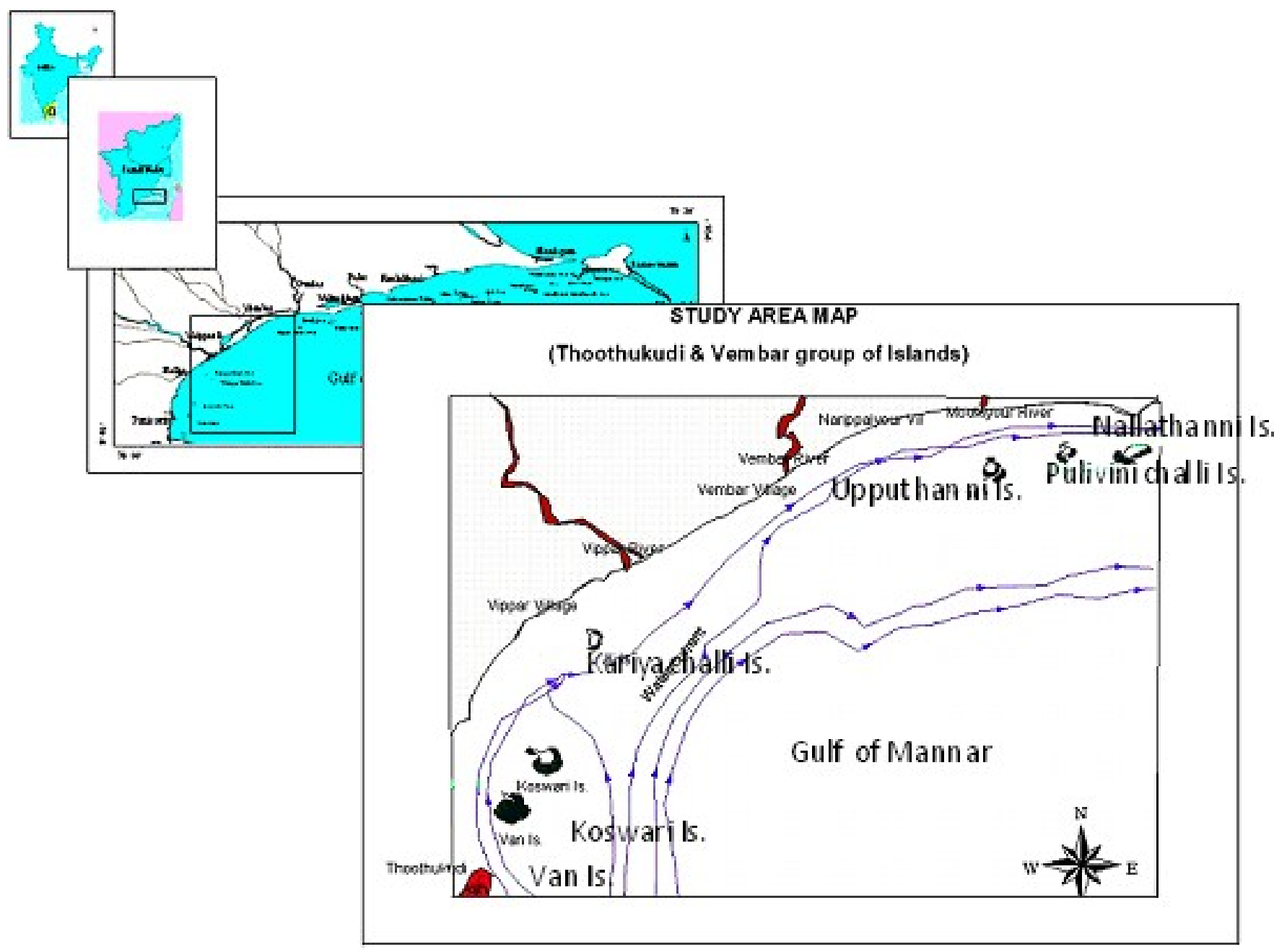

Figure 8. Map showing the study areas. 
The texture study of the collected samples indicated that most of samples are sand and silty sand texture, which indicated the winnowing action of wave. The higher percentage of sand fraction observed in the Van Island throughout the year was due to the prevalence of strong convergence of waves, which shift the sediment northerly (Angusamy et al., 1998; Ramanujam et al., 1995; 1998; 2003), this leads to the erosion of land on the seaward side and accretion of sediment on the landward side of islands of the study area (Thanikachalam and Ramachadran, 2002). It has been reported that the sedimentary organic carbon influences the occurrence and distribution of benthic fauna of the area (Alongi, 1986; Bhat and Neelakantan, 1988; Ansari et al., 1994). It is generally believed that moderate enrichment with organic matter has a bio-stimulating effect on the benthic community (Ansari et al., 1986, 1994). However, it has been pointed out that high concentration of organic matter will lead to eutrophication and provide unstable environmental conditions for benthic life (Ansari et al., 1994). Study of organic carbon in the sediments is of potential significance, for a proper understanding of water flow in aquatic ecosystems (Nair et al., 1983). Rain water run off through the rivers also play an important role in the accumulation of organic matter (Nixon and Lee, 1982; Purandara and Dora, 1984). In the present study the organic carbon level in all study stations ranged from 0.03 to 2.54 , which is similar to the early record reported by Jonathan et al. (2004) and Ramkumar et al. (2010) for the Tuticorin region of Gulf of Mannar (Fig. 8). A similar range was reported from east coast and south west coast of India by Mohan and Damodaran (1992); Mohan and Rajamanickam (1994).

The organic carbon content of sediment is an important parameter for benthic population (Kurian, 1972). The high inputs of terrigenous material from the adjacent land mass and industrial effluents nearby have contributed to the organic carbon values. The low values of OC ( 0.03 to $2.54 \%$ ) observed in the entire study area often accompanied by the time integrating nature of marine sedimentation and mixing processes at the sediment water interface where the rate of delivery as well as rate of degradation by a microbial medicated process could be high (Canuel and Martens, 1993). The sandy and shallow nature of the coastal region also supported the above inference (Rozonov et al., 1974). The low amount of organic carbon in the study stations have appeared to be favorable for the growth of corals and associated benthic fauna (Vinithkumar et al., 1999).

In the present study, the sediment of the six studied stations was found to be highly acidic in nature. According to Vinithkumar et al. (1999), high $\mathrm{pH}$ value has been recorded in coral reef sediments. It may be due to the sedimentation and suspended sediments in the water column. The low level of carbon silt and clay observed and high level of sand particles in the sediments observed in all study area in the present study may be the reason for the high $\mathrm{pH}$ value observed (Purandara and Dora, 1984; George Thomas, 1995).

The textural properties of the sediments in the present study showed that though sandy material dominated all through the year, other fractions were also represented. The present study revealed that the particle size, percentage of organic carbon and $\mathrm{pH}$ of the sediment are similar to that of the sediments of a tropical coast.

Though Gulf of Mannar faces the effects of two monsoons, northeast and southwest and also various anthropogenic impacts such as destructive fishing practices, discharge of domestic sewage and other industrial effluents and coastal developmental activities, the sedimentation rate recorded during the 12 months study period did not show any deleterious impact on the natural reefs. The rate of sedimentation was also comparatively high during some months, but it did not affect the growth of the corals significantly as the temperature fluctuation did. No bleaching and mortality was observed because of sedimentation during the entire study period. 


\section{ACKNOWLEDGEMENTS}

Authors wish to thank Shri. Senbagamoorthy, Department of Forest, and Ramnad District for the help they rendered for permission to survey the Islands. Authors also wish to express their sincere gratitude to the staff of Peoples Action for Development, NGO, Vembar especially to the Executive Director Mr. Rajendraprasad for the help in field surveys.

\section{References}

[1] Alongi D. M., Aust. J. Mar. Freshwater Res. 37 (1986) 609-919.

[2] Angusamy N., Udayaganesan P., Victor Rajamanickkam G., Indian. J. Mar. Sci. 27 (1998) 173-178.

[3] Ansari Z. A., CHatterji A., Parulekar A. H., Indian J. Mar. Sci. 23 (1986) 225-231.

[4] Ansari Z. A., Sreepada R. A., Kanti A., Indian. J. Mar. Sci. 23 (1994) 225-231.

[5] Bastidas C., Bone D., Garcia E. M., Marine Pollution Bulletin 38(1) (1999)16-24.

[6] Bhat U. G., Neelakantan B., Indian. J. Mar. Sci. 17 (1988) 134-142.

[7] Boto K. G., Wellington J. T., Estuaries. 7 (1) (1984) 61-69.

[8] Bray R. N., Clark S. (2004). Dredging and coral: a decision support system for managing dredging activities in coral reef ecosystems. WODCON XVII Hamburg, Germany: A3-2.

[9] Brock V. E., Van Heukelem W., Helfrich P., Hawii Inst. Mar. Biol.Tech. Rep. 11 (1966) $1-56$.

[10] Brown B. E., Howard L. S., Adv. Mar. Biol. 22 (1985) 1-63.

[11] Buddemeir R. W., Hopley D., (1998). Turn- ons and turn - offs: causes and mechanisms of the initiation and termination of coral reef growth. Proceeding of the Sixth International Coral Reef Congress, pp. 253-261.

[12] Canuel E. A., Martens C. S., Org. Geochem. 20(5) (1993) 563-577.

[13] Chandran R, Thangaraj G. S., Sivakumar V., Sreekrishna Das B., Ramamoorthi K., Indian. J. Mar. Sci. 11 (1982) 122-127.

[14] Chansang H., Boonyanate P., Charuchinda M. (1981). Effect of sedimentation from coastal mining on coral reefs on the northwestern coast of Phuket Island, Thailand Proc. $4^{\text {th }}$ int. Coral Reef. Symp. 1 (1981) 129-136.

[15] Chatterji A., Ansari Z. A., Mishra J. K., Parulekkar A. H., Indian. J. Mar. Sci. 24 (1995) 49-55.

[16] Cortes J., Risk M. J., Costa Rica. Revta Biol. Trop. 32 (1984) 109-121.

[17] Dahl A. L., (1985). Status and conservation of South Pacific coral reefs. Proc. $5^{\text {th }}$ int. Coral Reef Congr. 6 (1985) 509-513. 
[18] Dollar S. J, Grigg R. W., Mar. Biol. 65 (1981) 269-276.

[19] Edmunds P. J., Spencer-Davies P., Coral reefs 8 (1989) 37-43.

[20] Endean R., (1976). Destruction and recovery of coral reef communities. In: Jones, O.A., Endean R (eds). Biology and geology of coral reefs, Vol. 3. Biology 2 Academic Press, New York p. 215-254.

[21] English S., Wilkinson C., Baker V. (eds.) (1997). Survey manual for Tropical Marine Resources. Australian Institute of Marine Science, Townsville, Australia, 390 p.

[22] Fortes M. (2000). The effects of siltation on tropical coastal ecosystems. In: Wolanski E (Ed.), Oceanographic Processes of Coral Reefs. CRC Press. Boca Raton, pp. 93-112.

[23] George Thomas (1995). Comparative studies on the Ecobiology of Mangrove communities along the backwater system of Kerala. Ph.D. Thesis, University of Kerala, Trivandrum.

[24] Grigg D. I., Crean R. F., Van Eepoel R. P., Caribb Res. Inst. Water Pollution report. Rep. 15 (1972) 1-40.

[25] Harkantra S. N., Parulekar A. H., Indian J. Mar. Sci. 16 (1987) 57-59.

[26] Hodgson G., Dixon J. A. (1988). Logging versus Fisheries and tourism in Palawan. Occasional papers of the East-West Environment and Policy Institute, Honolulu. Paper no.7, p. 1-95.

[27] Hubbard D. K., Coral Reefs 5 (1986) 117-125.

[28] Hubbard D. K., Scature D., Bull. Mar. Sci. 32 (1985)890-908.

[29] Hudgson G., Dixon J. A. (1992). Sedimentation damage to marine resource: Environments and economic analysis. In JB Marsh (ed) Resources and environment in Asia's marine sector, pages 421-446. Taylor and Francies, Washington, DC 457pp.

[30] Isdale P. (1984). Fluorescent bands in massive corals record centuries of coastal rainfall. Nature, Lond 310: 578-579

[31] Jonathan M. P., Rammohan V., Srinivasalu .S (2004). Geochemical variations of major and trace elements in recent sediments, off the Gulf of Mannar, the southeast coast of India 45, 466-480.

[32] Krumbein W. C., Pettijohn F. J. (1938). Manual of sedimentary petrology. New York, NY; Appleton, Century and Crofts. 1-549.

[33] Kurian C. V., Proceeding National Institute Science India 38B (1972) 156-163.

[34] Machintyre I., Bull. Am. Ass. Petrol. Geol. 72 (1988) 1360-1369.

[35] Marsh J. A., Jr. Gordon G. D., Univ. of Guam Mar. Lab. Tech. Rep. 8 (1974) 1-56.

[36] Mathews G., Patterson Edward J. K. (2006). Effect of sedimentation and pollution in the reefs of Thoothukudi coast of Gulf of Mannar, Southeast coast of India. In: Proceedings of 10th International Coral Reef Symposium, Okinawa, Japan: 837 - 841.

[37] Mohan P.M., Rajamanickam G. V., The J of the Geol. Society of India 44 (1994) $575-580$. 
[38] Mohan P. M., Damodaran K. T., Indian J. Mar. Sci. 21 (1992) 300-302.

[39] Muthu Raj S., Jayaprakash M., Environ Geol 56 (2008) 207-217.

[40] Nair N. B., Thampy D. M. (1980). A. Textbook of Marine Ecology. Macmillan Co. India. Ltd., Delhi. 352.

[41] Nair N. B., Aziz P. K. A., Arunachalam M., Krishnakumar K., Bala Subramaniam N. K., Mahasagar 17(1) (1984) 19-32.

[42] Nair N. B., Krishna Kumar K., Arunachalam M., Abdul Aziz P. K., and Dharmaraj K., Indian. J. Mar. Sci. 12 (1983) 225-227.

[43] Nixon S. W., Lee V., Technical paper in Marine Sciences 33 (1982) 255-348.

[44] Ogston A. S., Storlazzi C. D., Field M. E., Presto M. K. (2004). Currents, Suspended sediment transport on a shallow reef flat: South - central Molokai, Hawaii, coral reefs.

[45] Purandara B. K., Dora Y. L. (1984). Studies on the texture and Organic matter in the sediments of Vembanad lake near shore sediments. Proc. Nat. Sem. Estuarine Management, 1987. Trivandrum. 440-452.

[46] Ram Kumar R., Patterson Edward J. K., World J. of Fish and Mar. Sciences 2(1) (2010) 70-77.

[47] Ramanujam N., Mukesh M. (1998). Deterioration of coral Islands of Thoothukudi group: Human Impacts. Biodiversity of Gulf of Mannar Marine Biosphere Reserve. Proc. Tech. Workshop held at Chennai: 69-75.

[48] Ramanujam N., Mukesh M., Sabeen H. M., and Preeja N. B., J. of Geo. Survey of India 45 (1995) 703-708.

[49] Ramanujam N., Sudarsan R., A Gulf of Mannar. Envi. Geol. 43 (2003) 521-525.

[50] Rogers C. S., J. Experi. Mar. Biol. and Ecol. 41 (1979) 269-288.

[51] Rogers C. S., Mar. Ecol. Progress Series 62 (1990) 185-202.

[52] Rozanov A. G., Volkov I. I., Yagodinskaya T. A. (1974). Forms of iron in the surface layer of black sea sediments. In: Degens ET, Ross DA (eds.). The black sea geology chemistry - biology. Amer. Assoc. pet. Geol. Mem. 20: 532-541.

[53] Souter E., Campbell P. G., Ribeyre F., Boudou A., Inter. J. Envi. Analytical Chemistry 54 (1993) 57-68.

[54] Stephen-Pichaimani V, et al., SE coast of India. Envi. Geol. 55 (2008) 1811-1819.

[55] Thanikachalam M., Ramachandran S. (2002). Management of coral reefs in Gulf of Mannar using Remote sensing and GIS techniques- with reference to coastal geomorphology and land use. Map Asia 2002, Asian conference on GIS, Aerial Photography and Remote Sensing, held at Bankok from August 7-9, 2002, http://WWW.gisdevelopment. Net.

[56] Van Katwijk M. M., et al., Mar. Biol. 117 (1993) 675-683.

[57] Vinithkumar N. V., Kumaresan S., Manjusha M., Balasubramanian T., Indian J. Mar. Sci. 28 (1999) 383-393. 
[58] Walkley A., Black T. A., Soil Science. 37 (1934) 23-38.

[59] Weber J. N., White E. W., Mar. Biol. 26 (1974) 353-359.

[60] Wright L. D. (1995). Morphometric of inner continental shelves. CRC Press.

( Received 21 November 2013; accepted 25 November 2013 ) 